\title{
Antifungal effect of plant extracts on Candida albicans biofilm on acrylic resin
}

Efeito antifúngico de extratos vegetais sobre biofilme de Candida albicans em resina acrilica

Jonatas Rafael de OLIVEIRA ${ }^{1}$, Polyana das Graças Figueiredo VILELA ${ }^{1}$, Felipe Eduardo de OLIVEIRA ${ }^{1}$, Kely Karina BELATO ${ }^{1}$, Cláudio Antonio Talge CARVALHO ${ }^{2}$, Antonio Olavo Cardoso JORGE ${ }^{1}$, Luciane Dias de OLIVEIRA ${ }^{2}$

1 - Institute of Science and Technology - UNESP - Univ Estadual Paulista - Department of Biosciences and Oral Diagnosis - Laboratory of Microbiology and Immunology - São José dos Campos - SP - Brazil.

2 - Institute of Science and Technology - UNESP - Univ Estadual Paulista - School of Dentistry - Department of Restorative Dentistry - São José dos Campos - SP - Brazil.

\section{ABSTRACT}

Objective: Evaluating the antifungal potential of Equisetum arvense L. (horsetail), Glycyrrhiza glabra L. (licorice), Punica granatum L. (pomegranate) and Stryphnodendron barbatimam Mart. (barbatimão) extracts, after Candida albicans biofilm formation on acrylic resin. Material and methods: C. albicans standard strain was cultured on Sabourauddextrose agar for $24 \mathrm{~h}$ at $37^{\circ} \mathrm{C}$. After standardized in a spectrophotometer, $100 \mu \mathrm{L}$ of the inoculum $\left(10^{6}\right.$ cells $\left./ \mathrm{mL}\right)$ and a sterile acrylic resin disc were maintained in Brain Heart Infusion broth supplemented with sucrose (5\%), for 5 days at 37 ${ }^{\circ} \mathrm{C}$. The samples of the treated groups $(\mathrm{n}=10)$ were separately exposed to a concentration of $50 \mathrm{mg} / \mathrm{mL}$ of each extract for 5 minutes or to nystatin (48.83 $\mathrm{IU} / \mathrm{mL}$ ). For the untreated group (control, $\mathrm{n}=10$ ), it was used sterile saline $(0.9 \% \mathrm{NaCl})$. Biofilms were disaggregated from the acrylic resin discs by an ultrasonic homogenizer for 30 s. After decimal dilutions, sowings in Sabouraud-dextrose plates were made with incubation for $48 \mathrm{~h}$ at $37^{\circ} \mathrm{C}$. Later, $\mathrm{CFU} / \mathrm{mL}$ was verified and the values were converted to $\log _{10}$ and they had their statistical analysis done (ANOVA and Tukey Test, $\mathrm{p} \leq \mathrm{0.05}$ ). Results: It was found that all plant extracts and nystatin resulted in significant reduction of $C$. albicans biofilm ( $\mathrm{p}<$ $0.01)$ compared to the control group $(0.9 \% \mathrm{NaCl})$. However, all of them showed similar reductions to each other $(\mathrm{p}=0.1567)$. Conclusion: There was biofilm formation of $C$. albicans on acrylic resin and all plant extracts were effective against this yeast, acting similarly to nystatin.

\section{KEYWORDS}

Biofilm; Candida albicans; Medicinal plants; Nystatin; Plant Extracts.

\section{RESUMO}

Objetivo: Avaliar potencial antifúngico dos extratos de Equisetum arvense L. (cavalinha), Glycyrrhiza glabra L. (alcaçuz), Punica granatum L. (romã) e Stryphnodendron barbati-mam Mart. (barbatimão) sobre biofilme de Candida albicans em resina acrílica. Material e métodos: Cepa-padrão de $C$. albicans foi cultivada em ágar Sabouraud-dextrose por $24 \mathrm{~h}$ a $37^{\circ} \mathrm{C}$. Após padronização do inóculo $\left(10^{6}\right.$ células $/ \mathrm{mL}$ ) em espectrofotômetro, foram mantidos em caldo Brain Heart Infusion suplementado com sacarose (5\%) um disco de resina acrílica estéril com $100 \mu \mathrm{L}$ do inóculo padronizado, por 5 dias a $37^{\circ} \mathrm{C}$. As amostras dos grupos tratados $(\mathrm{n}=10)$ foram expostas separadamente à concentração de $50 \mathrm{mg} / \mathrm{mL}$ de cada extrato por 5 min e ao antifúngico nistatina (48.83 $\mathrm{UI} / \mathrm{mL}$ ). Para o grupo não tratado (controle, $\mathrm{n}=10$ ) foi utilizada solução fisiológica estéril ( $\mathrm{NaCl} 0,9 \%)$. Os biofilmes foram desagregados dos discos de resina acrílica por homogeneizador ultrassônico por $30 \mathrm{~s}$. Após diluições decimais, foram feitas semeaduras em placas de Sabouraud-dextrose e incubação por $48 \mathrm{~h}$ a $37{ }^{\circ} \mathrm{C}$. Posteriormente, foram contadas as $\mathrm{UFC} / \mathrm{mL}$ e os valores foram convertidos em $\log _{10}$ e realizada análise estatística (ANOVA e Tukey Test; $p$ $\leq 0,05$ ). Resultados: Todos os extratos naturais e a nistatina proporcionaram reduções significativas (p $<0,01$ ) do biofilme de $C$. albicans em comparação ao grupo controle ( $\mathrm{NaCl} 0,9 \%$ ), no entanto, não houve diferença estatística entre os extratos ( $\mathrm{p}=$ 0,1567). Conclusões: Houve formação de biofilme de C. albicans em resina acrílica e todos os extratos vegetais foram efetivos para esta levedura, atuando semelhantemente à nistatina.

\section{PALAVRAS-CHAVE}

Biofilme; Candida albicans; Plantas medicinais; Nistatina. 


\section{INTRODUCTION}

$\mathrm{B}$ iofilms are well structured microbial communities where cells are embedded in an extracellular polysaccharide matrix, with the majority of the cells anchored to a substrate and these sessile cells are phenotypically different from planktonic cells or free floating cells [1].

C. albicans is the most common opportunistic fungal pathogen agent isolated from the human body, being able to cause superficial or systemic infections, often after antibiotic treatments, more severe in immunocompromised patients [2].

One of the most important virulence factors of Candida species is biofilm formation, because it provides the yeast resistance to antifungal drugs and complicates the diffusion of defense substances and cells by extracellular matrix [3]. Biofilm formation of Candida species is very common in dental prostheses [4], however, other infections related to the formation of biofilm on implanted materials have been reported, especially in urinary catheters, intravascular devices, bone fixation materials, central venous catheters, pacemakers, vascular grafts, heart valves and mechanical prostheses [5]. There are factors that predispose to Candida infections, such as immunosuppressive therapy, antibiotic use, HIV infection, diabetes, advanced age and use of implanted devices for a long time [6].

With the increasing number of microbial strains that have acquired resistance to conventional antibiotics, the search for alternative methods for controlling and treating infections caused by these strains is of great importance. The use of products from plants is one of these methods because it can provide significant results in the elimination of opportunistic pathogenic microorganisms like C. albicans.

Equisetum arvense L. (Equisetaceae) is a plant from Europe that grows well in temperate areas in different parts of the world. It is popularly known in Brazil as "cavalinha" (horsetail). There are reports of antibacterial activity for Staphylococcus aureus, Escherichia coli, Salmonella enteritidis, Klebsiella pneumoniae, Pseudomonas aeruginosa and antifungal activity for Aspergillus niger and $C$. albicans [7]. Therefore, it becomes interesting to analyze its effects on microbial biofilm.

Glycyrrhiza glabra L. (Fabaceae) is a native plant of the Mediterranean region, but it can develop in various parts of the world that have temperate climate [8]. His popular name in Brazil is "alcaçuz" (licorice). Its roots are indicated as responsible for lots of biological and therapeutic activities, such as antimicrobial activity for strains of $S$. aureus, methicillinresistant $S$. aureus (MRSA), Micrococcus luteus, Bacillus subtilis, E. coli, K. pneumoniae and $P$. aeruginosa [9]. However, there are few studies on their antifungal activity.

Punica granatum L. (Punicaceae) had its origin recorded in the Mediterranean region [10]. In Brazil, it is called "romã" (pomegranate). Its antimicrobial activity is proven by numerous studies which suggest that the interaction of compounds of $P$. granatum L. with cell membrane of bacteria and yeast affect its integrity, promoting elimination of these microorganisms [11]. Researches with the peel and the flowers of this fruit proved its antifungal potential [12]. It was also observed antimicrobial activity of $P$. granatum L. on $B$. subtilis, E. coli, Saccharomices cerevisiae [13], $K$. pneumoniae, Proteus vulgaris, Salmonella typhy [14], Bacillus cereus, B. coagulens, P. aeruginosa [10] and it is of great interest to analyze its effects on biofilm.

Stryphnodendron barbatimam Mart. (Leguminosae), is derived from Brazilian Cerrado and is popularly known as "barbatimão." Its effectiveness was reported on Streptococcus mutans, S. aureus, Actinobacillus actinomycetemcomitans, C. albicans, Cryptococcus neoformans $[15,16]$. The extract of this plant can affect the integrity of its cell wall, decrease its ability to adhere, inhibit formation of its germ tube, interfere in the process of budding 
and stimulate phagocytosis by macrophages [17]. This is an extract of great importance for possible clinical applications in dental clinics.

The emergence of strains resistant to conventional antimicrobial use occurs constantly. So, it has became of great relevance to search for alternative methods that can eliminate these microorganisms. The use of medicinal plants is one of these methods, which have shown effective results in controlling pathogens. Thus, it was evaluated in the present study the antifungal activity of the extracts of E. arvense L., G. glabra L., P. granatum L. and $S$. barbatimam Mart. on C. albicans biofilm on acrylic resin.

\section{MATERIAL AND METHODS}

This study was approved by the Ethics Committee of the Faculty of Dentistry of São José dos Campos - UNESP / FOSJC according to the protocol 008/2010-PA/CEP.

Experimental groups: products evaluated in biofilms of $C$. albicans

The extracts of E. arvense L., G. glabra L., $P$. granatum L. and $S$. barbatimam Mart. were prepared at a concentration of $200 \mathrm{mg} /$ $\mathrm{mL}$ in propylene glycol, after acquisition of the dry powders from Oficina de Ervas (Ribeirão Preto, SP, Brazil). After preliminary tests on planktonic cultures of $C$. albicans, it was used at a concentration of $50 \mathrm{mg} / \mathrm{mL}$ on biofilms.

It was used the nystatin $(100,000 \mathrm{IU} /$ $\mathrm{mL}$ - Cristália, Itapira, SP, Brazil) as a control to compare the action of natural extracts. After preliminary tests on planktonic cultures of yeast, it was adopted the concentration of $48.83 \mathrm{IU} /$ $\mathrm{mL}$ to be applied on the biofilm. Sterile saline $(0.9 \% \mathrm{NaCl})$ was used in the non-treated group (control).

Antimicrobial activity of the products in biofilms of $C$. albicans

In order to evaluate the antifungal activity of plant extracts and nystatin, it was used a standard strain of C. albicans (ATCC 18804), grown on Sabouraud-dextrose (HIMEDIA, Mumbai, Maharashtra, India) for $24 \mathrm{~h}$ at 37 ${ }^{\circ} \mathrm{C}$. The inoculum was standardized in sterile saline $(0.9 \% \mathrm{NaCl})$ with spectrophotometer (B582, Micronal, São Paulo, SP, Brazil) with a wavelength of $530 \mathrm{~nm}$ and optical density of $0.284 \pm 0.20$, to obtain a suspension of $10^{6}$ cells $/ \mathrm{mL}$.

Biofilm formation [18] was performed in 100 sterile disks of acrylic resin (Classic, São Paulo, SP, Brazil), submerged in $2 \mathrm{~mL}$ of Brain Heart Infusion broth (BHI - HIMEDIA) supplemented with 5\% sucrose with $100 \mathrm{~mL}$ of standardized suspension of $C$. albicans. The discs were maintained in sterile 24 well plates with a cover (TPP, Trasadingen, Schaffhausen, Switzerland) at $37{ }^{\circ} \mathrm{C}$ for 5 days. Subsequently, the disks underwent two washes in sterile physiological solution $(0.9 \% \quad \mathrm{NaCl})$. The experimental groups $(\mathrm{n}=10)$ were divided according to the tested product: $E$. arvense L. $(50 \mathrm{mg} / \mathrm{mL})$, G. glabra L. $(50 \mathrm{mg} / \mathrm{mL})$, P. granatum L. $(50 \mathrm{mg} / \mathrm{mL}), S$. barbatimam Mart. (50 mg/mL), nystatin $(48.83 \mathrm{IU} / \mathrm{mL}$ ) and untreated (Control - $\mathrm{NaCl} 0.9 \%$ ). After 5 minutes of contact with the products, under agitation, the discs were washed again and subjected to ultrasonic agitator (Sonoplus HD 2200, Bandelin Electronic, Berlin, Germany) for $30 \mathrm{~s}$ in order to dissociate the biofilm. Then, it was obtained a suspension with the dissociated biofilm and from this suspension, four decimal dilutions were performed $(1: 10 ; 1: 100 ; 1: 1,000$; $1: 10,000)$ and $100 \mu \mathrm{L}$ of each were plated in duplicate on Sabouraud-dextrose. After $48 \mathrm{~h}$ incubation $\left(37^{\circ} \mathrm{C}\right)$, plates containing $30-300$ colonies were counted for colony forming units per milliliter (CFU/mL).

\section{Statistical Analysis}

The results were converted into $\log _{10}$. Mean values and standard deviations were statistically analyzed by ANOVA, complemented by Tukey Test, with $5 \%$ significance ( $\mathrm{p} \leq 0.05)$, with the aid of statistical program BioEstat 5.0. 


\section{RESULTS}

As it can be seen in Figures 1 and 2, the group treated with $E$. arvense L. showed reduction on $C$. albicans biofilm of $1.068 \pm$ $0.660 \log _{10}$, equivalent to $18 \%$ compared to the control group $(0.9 \% \mathrm{NaCl})$. The group that received treatment with extract of G. glabra L. showed a reduction of $24 \%(1.310 \pm 0.457)$.
In the group treated with $P$. granatum L., reductions were of approximately 26\% (1.463 \pm $0.338)$. The biofilms treated with $S$. barbatimam Mart. showed a reduction of approximately $27 \%$ $(1.549 \pm 0.418)$ relative to nystatin antifungal, reductions averaged $21 \%(1.257 \pm 0.265)$. However, it was observed that the reductions in the biofilm of $C$. albicans presented in all treated groups were statistically similar $(\mathrm{p}=0.1567)$.

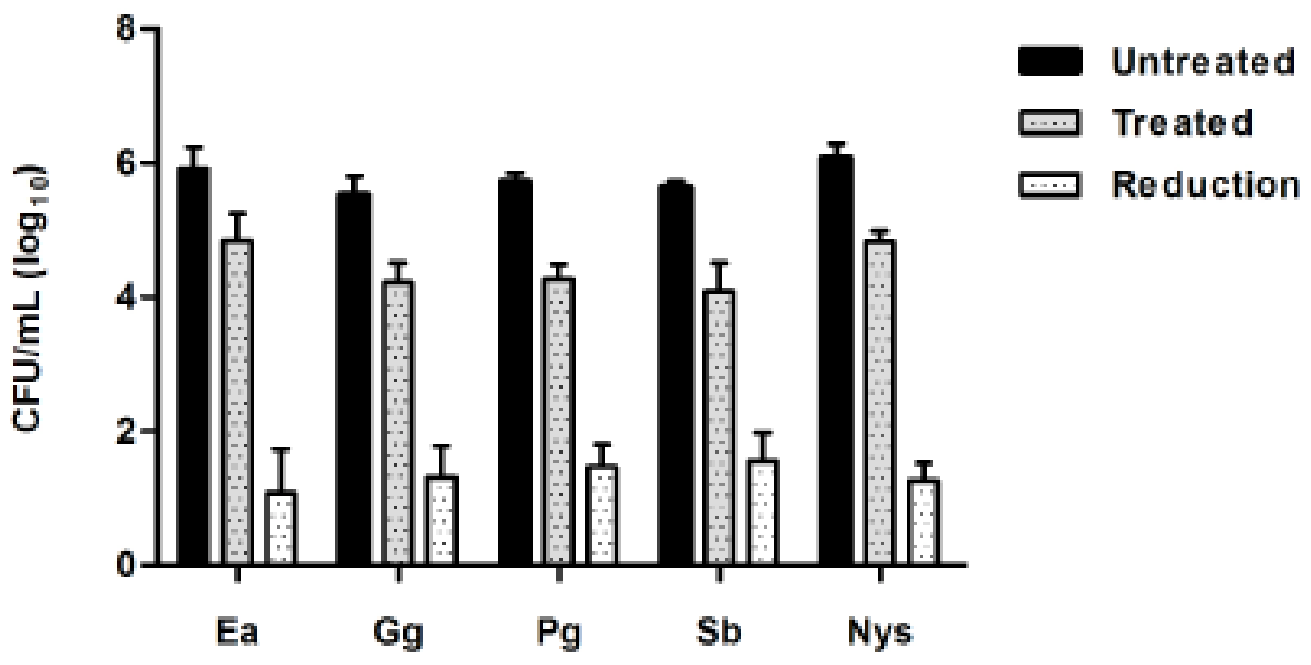

Figure 1- Mean ( \pm SD) of CFU/mL ( $\log _{10}$ ) of the biofilm of C. albicans obtained in the untreated group ( $\mathrm{NaCl} 0.9 \%$ ) and treated groups with $50 \mathrm{mg} / \mathrm{mL}$ of extracts of E. arvense L. (Ea), G. glabra L. (Gg), P. granatum L. (Pg) and S. barbatimam Mart. (Sb) and nystatin (Nys) $48.83 \mathrm{IU} / \mathrm{mL}$. In all groups there was a significant biofilm reduction when compared to the control group, non-treated ( $p<0.01)$. There was no difference in the reduction between the treated groups $(p<0.05)$. ANOVA, Tukey Test $(p \leq 0.05)$.

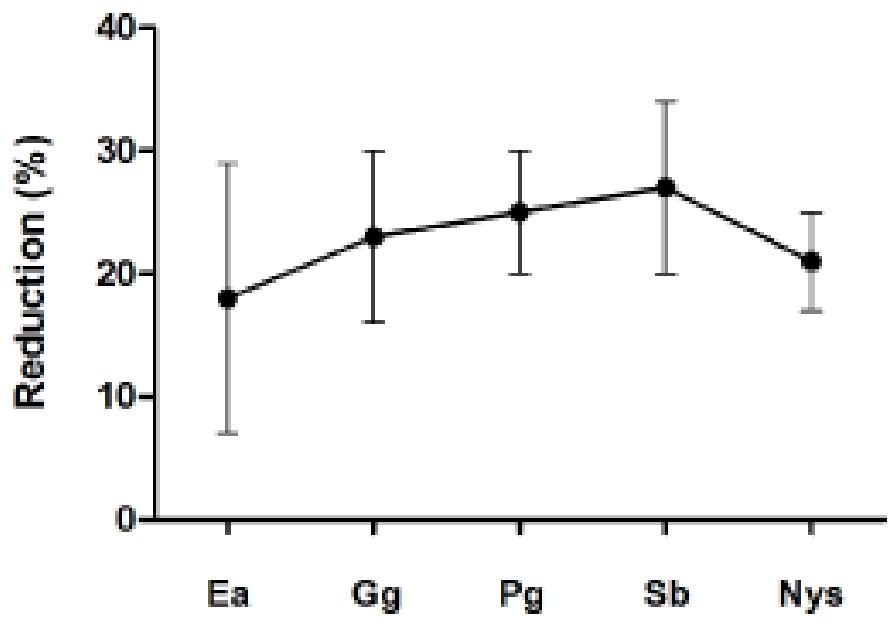

Figure 2 - Reduction percentage of $C$. albicans biofilm after 5-minute treatment with the extracts of E. arvense L. (Ea), G. glabra L. $(\mathrm{Gg})$, P. granatum L. (Pg) and S. barbatimam Mart. (Sb) and the antifungal nystatin (Nys). The reductions were statistically similar ( $p>$ 0.05). ANOVA, Tukey Test ( $p \leq 0.05)$. 


\section{DISCUSSION}

Taking into consideration the time of exposure of the biofilm to treatment (5 minutes) with different plant extracts and their concentrations, all groups treated with extracts of E. arvense L., G. glabra L., P. granatum L. and $S$. barbatimam Mart. or nystatin exhibited significant reductions in biofilm of $C$. albicans ( $\mathrm{p}<0.05$ ), compared to the untreated group ( $\mathrm{NaCl}$ 0.9\%) (Figures 1 and 2), however, these reductions were statistically similar ( $p>$ 0.05). Ishida et al. (2006) [17] also found that the antifungal activity of the extract fractions was similar to Stryphnodendron adstringens presented by the nystatin and fluconazole on $C$. albicans inhibiting the growth of the yeast.

Considering the clinical application or popular use of these products, it would be convenient to use them with less exposure time, such as 30 or $60 \mathrm{~s}$ for a mouth rinse, however, we extrapolated this period of exposure for five minutes, taking into consideration the possibility of adding the bioactive components of these plant extracts to dentifrices, for instance, where the exposure time is increased. In this in vitro study, we found effective reduction of the biofilm exposed to extracts for 5 minutes.

In preliminary tests on planktonic cultures of C. albicans, it was determined Minimum Fungicidal Concentration (MFC) of all extracts, i.e., $50 \mathrm{mg} / \mathrm{mL}$ [19]. Based on these results, we sought in this study to verify the effectiveness of this concentration on C. albicans biofilm, in vitro, being confirmed its fungistatic activity for the biofilm. Watamoto et al. (2009) [20] checked the action of some antifungals as amphotericin B, nystatin, caspofungin, ketoconazole and 5 -flucytosin against $C$. albicans strains, including mutant strains, and also determined inhibitory concentrations for biofilm growth above the levels found in planktonic cultures for all antifungals studied.

The extracts were prepared in propylene glycol, however, when we checked its possible influence on the results of antimicrobial plant products, we found that the concentration of 50 $\mathrm{mg} / \mathrm{ml}$ propylene glycol showed no antifungal effect for C. albicans planktonic cultures, therefore, we didn't continue the tests on biofilm.

It was also verified that nystatin, used as control in this study, presented antifungal action against planktonic cultures and its MFC was $48.83 \mathrm{IU} / \mathrm{mL}$. This antifungal was commercially purchased at a concentration of $100,000 \mathrm{IU} / \mathrm{mL}$ and it was indicated for oral administration of $5 \mathrm{~mL}$. However, we found convenient to check its action using the same MFC presented by plant extracts. Endo et al. (2012) [21] studied microparticles composed by the extract of $P$. granatum $\mathrm{L}$. and observed active role on $C$. albicans planktonic and biofilm elimination, whose controls were nystatin and fluconazole. These authors also found that nystatin has presented the minimum inhibitory concentration (MIC) of $3.9 \mathrm{mg} / \mathrm{mL}$ while $P$. granatum $\mathrm{L}$. in planktonic culture showed MIC of $3.1 \mathrm{mg} / \mathrm{mL}$, demonstrating that the antifungal effect was similar between a product of known efficacy and a plant extract. Thus, we can see a correlation between the study of Endo et al. (2012) [21] and our study, regarding the similarity of the antifungal activity presented by plant extracts (including extract of $P$. granatum L.) and nystatin, which was used at a concentration equivalent to that of plant extracts.

Products from plants such as essential oils and extracts, have several chemical compounds which may exhibit various biological functions such as anti-inflammatory, antioxidant, antitumor, anti-allergic, antiviral, antibacterial, antifungal activity, etc. Thymol, a compound present in E. arvense L., showed antimicrobial activity [22]. Besides, it was observed strong antifungal action of this compound in combination with 1,8-cineole [23]. Glabridin [9], glycyrrhizin and 18- $\beta$ glycyrrhetinic acid, G. glabra L. compounds [24,25] were shown to be responsible for the antimicrobial activity of the plant, and 18- $\beta$ glycyrrhetinic acid showed inhibitory effect for $C$. albicans [26]. It has been demonstrated by studies that the antimicrobial 
effect of $P$. granatum L. is related to the presence of phenols, such as tannins, which react with the proteins of the microorganism and make these molecules become inactivated in the presence of their substrates [27]. The punicalagin is another $P$. granatum L. compound, which shows activity on microorganisms [28]. The antimicrobial effect of Stryphnodendron spp. is also due to the presence of tannins [17] and gallic acid [29].

The ability of biofilm formation is a major virulence factor presented by $C$. albicans and it gives this microorganism greater chance of resistance to the action of antifungal agents when compared to planktonic growth $[6,30]$. Factors such as the presence of extracellular matrix, gene expression induced by intercellular contact and antioxidant capacity provide the biofilm of $C$. albicans high antifungal resistance $[31,32]$. The success of the formation of a mature biofilm is related to the adhesion to a surface, its colonization and survival, including the competition between different microorganisms [20].

It was demonstrated in this study that the analyzed natural products performed significantly control of $C$. albicans biofilm on acrylic resin and it was demonstrated that they can be as efficient as the use of conventional products, such as nystatin, commonly used in the treatment of candidosis. Thus, we believe that future studies should be conducted, related to development of products for dental use as mouthwashes or toothpastes, based on isolated active principles of plants studied here. Other research that verify in vivo application of these products should also be conducted to verify their biocompatibility in humans, targeting the therapeutic use of these plant extracts.

\section{CONCLUSION}

According to the results, it was concluded that the extracts of E. arvense L., G. glabra L., $P$. granatum L. and S. barbatimam Mart. were effective in reducing $C$. albicans biofilm on acrylic resin, presenting antifungal activity similar to nystatin.

\section{REFERENCES}

1. Uppuluri P, Dinakaran H, Thomas DP, Chaturvedi AK, Lopez-Ribot $\mathrm{JL}$. Characteristics of Candida albicans biofilms grown in a synthetic urine medium. J Clin Microbiol. 2009 Dec;47(12):4078-83.

2. Pfaller MA, Diekema DJ. Epidemiology of invasive candidiasis: a persistent public health problem. Clin Microbiol Rev. 2007 Jan;20(1):133-63.

3. Estivill D, Arias A, Torres-Lana A, Carrillo-Muñoz AJ, Arévalo MP. Biofilm formation by five species of Candida on three clinical materials. J Microbiol Methods. 2011 Aug;86(2):238-42.

4. Kojic EM, Darouiche R0. Candida infections of medical devices. Clin Microbiol Rev. 2004 Apr;17(2):255-67.

5. Cauda R. Candidaemia in patients with an inserted medical device. Drugs. 2009 Nov;69(1):33-8.

6. Ramage G, Bachmann S, Patterson TF, Wickes BL, López-Ribot JL. Investigation of multidrug efflux pumps in relation to fluconazole resistance in Candida albicans biofilms. J Antimicrob Chemother. 2002 Jun;49(6):973-80.

7. Radulović N, Stojanović G, Palić R. Composition and antimicrobial activity of Equisetum arvense L. essential oil. Phytother Res. 2006 Jan;20(1):85-8.

8. Gupta VK, Fatima A, Faridi U, Negi AS, Shanker K, Kumar JK, et al. Antimicrobial potential of Glycyrrhiza glabra roots. J Ethnopharmacol. 2008 Mar;116(2):377-80.

9. Fukai T, Marumo A, Kaitou K, Kanda T, Terada S, Nomura T. Antimicrobial activity of licorice flavonoids against methicillinresistant Staphylococcus aureus. Fitoterapia. 2002 0ct;73(6):536-9.

10. Negi PS, Jayaprakasha GK. Antioxidant and antibacterial activities of Punica granatum peel extracts. J Food Sci. 2003 May;68(4):1473-7.

11. Vasconcelos LC, Sampaio FC, Sampaio MC, Pereira Mdo S, Higino JS, Peixoto MH. Minimum inhibitory concentration of adherence of Punica granatum Linn (pomegranate) gel against $S$. mutans, $S$. mitis and C. albicans. Braz Dent J. 2006 Apr;17(3):223-7.

12. Fenner R, Betti AH, Mentz LA, Rates SMK. Plants with potencial antifungal activity employed in Brazilian folk medicine. Rev Bras Cienc Farm. 2006 Jul;42(3):370-93.

13. Das AK, Mandal SC, Banerjee SK, Sinha S, Das J, Saha BP, Pal M. Studies on antidiarrhoeal activity of Punica granatum seed extract in rats. J Ethnopharmacol. 1999 Dec;68(1-3):205-8.

14. Prashanth D, Asha MK, Amit A. Antibacterial activity of Punica granatum. Fitoterapia. 2001 Feb;72(2):171-3.

15. Ishida K, Rozental S, de Mello JC, Nakamura CV. Activity of tannins from Stryphnodendron adstringens on Cryptococcus neoformans: effects on growth, capsule size and pigmentation. Ann Clin Microbiol Antimicrob. 2009 Nov;8:29.

16. Santos VR, Gomes RT, Oliveira RR, Cortés ME, Brandão MGL. Susceptibility of oral pathogenic microorganisms to aqueous and ethanolic extracts of Stryphnodendron adstringens (barbatimão). Int J Dent. 2009 Jan;8(1):1-5.

17. Ishida K, de Mello JC, Cortez DA, Filho BP, Ueda-Nakamura T, Nakamura CV. Influence of tannins from Stryphnodendron adstringens on growth and virulence factors of Candida albicans. J Antimicrob Chemother. 2006 Nov;58(5):942-9. 
18. Pereira CA, Romeiro RL Costa AC, Machado AK, Junqueira JC, Jorge A0. Susceptibility of Candida albicans, Staphylococcus aureus, and Streptococcus mutans biofilms to photodynamic inactivation: an in vitro study. Lasers Med Sci. 2011 May;26(3):341-8.

19. Oliveira JR, Castro VC, Vilela PGF, Camargo SE, Carvalho CAT, Jorge AOC, et al. Cytotoxicity of Brazilian plant extracts against oral microorganisms of interest to dentistry. BMC Complement Altern Med. 2013 Aug;13:208.

20. Watamoto T, Samaranayake LP, Jayatilake JA, Egusa $\mathrm{H}$, Yatani $\mathrm{H}$, Seneviratne CJ. Effect of filamentation and mode of growth on antifungal susceptibility of Candida albicans. Int J Antimicrob Agents. 2009 0ct;34(4):333-9.

21. Endo EH, Ueda-Nakamura T, Nakamura CV, Filho BP. Activity of spray-dried microparticles containing pomegranate peel extract against Candida albicans. Molecules. 2012 Aug;17(9):10094-107.

22. Tepe B, Daferera D, Sökmen M, Polissiou M, Sökmen A. In vitro antimicrobial and antioxidant activities of the essential oils and various extracts of Thymus eigii M. Zohary et P.H. Davis. J Agric Food Chem. 2004 Mar;52(5):1132-7.

23. Pina-Vaz C, Gonçalves Rodrigues A, Pinto E, Costa-de-Oliveira S, Tavares C, Salgueiro L, et al. Antifungal activity of Thymus oils and their major compounds. J Eur Acad Dermatol Venereol. 2004 Jan;18(1):73-8.

24. Fiore C, Eisenhut M, Ragazzi E, Zanchin G, Armanini D. A history of the therapeutic use of liquorice in Europe. J Ethnopharmacol. 2005 Jul;99(3):317-24.
25. Tsukiyama R, Katsura H, Tokuriki N, Kobayashi M. Antibacterial activity of licochalcone $A$ against spore-forming bacteria Antimicrob Agents Chemother. 2002 May;46(5):1226-30.

26. Pellati D, Fiore C, Armanini D, Rassu M, Bertoloni G. In vitro effects of glycyrrhetinic acid on the growth of clinical isolates of Candida albicans. Phytother Res. 2009 Apr;23(4):572-4.

27. Naz S, Siddiqi R, Ahmad S, Rasool SA, Sayeed SA. Antibacterial activity directed isolation of compounds from Punica granatum. J Food Sci. 2007 Nov;72(9):M341-5.

28. Machado TB, Leal ICR, Amaral ACF, Santos KRN, Silva MG, Kuster RM. Antimicrobial ellagitannin of Punica granatum fruits. J Braz Chem Soc. 2002 Aug;13(5):606-10.

29. Sanches ACC, Lopes GC, Nakamura CV, Filho BPD, Mello JCP. Antioxidant and antifungal activities of extracts and condensed tannins from Stryphnodendron obovatum Benth. Braz J Pharm Sciences. 2005 Jan;41(1):100-7.

30. Chandra J, Kuhn DM, Mukherjee PK, Hoyer LL, McCormick T, Ghannoum MA. Biofilm formation by the fungal pathogen Candida albicans: development, architecture, and drug resistance. J Bacteriol. 2001 Sep;183(18):5385-94.

31. LaFleur MD, Kumamoto CA, Lewis K. Candida albicans biofilms produce antifungal-tolerant persister cells. Antimicrob Agents Chemother. 2006 Nov;50(11):3839-46.

32. Seneviratne CJ, Jin LJ, Samaranayake YH, Samaranayake LP. Cell density and cell aging as factors modulating antifungal resistance of Candida albicans biofilms. Antimicrob Agents Chemother. 2008 Sep;52(9):3259-66.

\section{Jonatas Rafael de Oliveira \\ (Corresponding address)}

UNESP - Universidade Estadual Paulista

Instituto de Ciência e Tecnologia -

Departamento de Biociências e Diagnóstico Bucal

Laboratório e Microbiologia e Imunologia

Av. Engenheiro Francisco José Longo, 777 - Jardim São Dimas

São José dos Campos - SP, Brasil. CEP 12245-000.

Tel.: +55 12 3947-9334; Fax: +55 12 3947-9010

Date submitted: 2013 Jul 17

E-mail address: jroliveira16@hotmail.com 